\title{
Talent retention in a changing workplace: An investigation of variables considered important to South African talent
}

\author{
M. Birt, T. Wallis* \& G. Winternitz \\ Section of Organisational Psychology and Human Resource Management, \\ School of Management Studies, University of Cape Town, \\ Private Bag, Rondebosch 7701, Republic of South Africa \\ twallis@commerce.uct.ac.za
}

Received March 2004

\begin{abstract}
In a workplace characterised by market-driven turnover, organisations attempting to retain those employees considered core to their purpose and continued success (referred to as 'talent') face a huge challenge in determining the factors instrumental in minimising turnover amongst this group. This research aimed to identify the variables important to this group of valued employees, with a specific focus on the South African context. In addition, it was aimed to discover the relative importance of intrinsic and extrinsic variables to South African talent, particularly when these are considered as factors in their decisions to leave the organisation. It was found that South African talent placed great importance on intrinsic variables, although market opportunities were also considered highly significant in employees' decisions to leave. The variable of 'Concern with employment equity and affirmative action' was revealed as a specifically South African variable, but it was not ranked as one of the participants' top five most important variables influencing retention.
\end{abstract}

*To whom all correspondence should be addressed.

\section{Introduction}

Past employment relationships based on mutual commitment between employer and employee are no longer the norm in the marketplace (Cappelli, 2000b; Flood, 2002). Instead of a predictable linear rise up an organisation's hierarchy, careers are now characterised by a 'protean' model of movement between many organisations during the course of individuals' working lives (Feller, 1995; Flood, 2002; Kerka, 1995; Schreuder \& Theron, 2001). The main driver of these shifts in the employment system has been economic - during the 1990s, many organisations downsized, often drastically, in an attempt to cope with changing market conditions that demanded flexibility in order to survive (Cappelli, 2000b). Interestingly, however, these organisational actions had an unexpected and largely unanticipated outcome, namely a definite shift in power in the employment relationship from employers to employees.

The new power-base in the labour market is a group of employees referred to, variously, as 'knowledge workers' (e.g. Stewart, 1997) or 'talent' (e.g. Paton, 2002). These are employees who have embraced the new career model, which matched their needs for greater career freedom, and who have sought-after knowledge and skills that place them in demand by organisations (Cappelli, 2000b). Capturing this knowledge in organisational systems and databases is often not an option, as this group of employees also possess what Quinn, Anderson and Finkelstein (1996) referred to as systems understanding and self-motivated creativity. The former allows these employees to solve complex problems through understanding the often subtle cause-and-effect relationships involved, while the latter is a personal attribute that keeps these employees motivated and adaptable to changes. The value created by these types of characteristics means that '[organisations] need knowledge workers far more than knowledge workers need them' (Drucker, no date, cited in Stewart, 1997: 68).

As a result of this, while organisations may be willing to forego commitment from many of their employees in exchange for the benefits of increased flexibility and responsiveness to environmental changes, this does not apply to those employees classed as talent (Feller, 1995). This is because the organisation's competitive advantage is often dependent on the specialised knowledge and skills possessed by these employees (Schreuder \& Theron, 2001). Given that these employees carry the "[tools of their trade] between [their] ears' (Stewart, 1997: 68), retaining this knowledge becomes a matter of retaining these employees, since their leaving means a loss to the organisation of its intellectual capital or intangible assets (Arkin, 2001; Buckingham, 2000; DeConinck \& Bachmann, 1994; Kaye \& Jordan-Evans, 2000; Michand, 2001; Sveiby, 1997). Talent management should be seen as a strategic business priority (Towers Perrin, no date, cited in HR Focus, 2003, $80(1): 3$ ) and for this reason, the organisation is prepared to invest in the careers of these employees in order to increase their organisational commitment and avoid the phenomenon of market-driven turnover (Corporate Leadership Council (CLC), 1998a; Harvard Business Review, 2000; Feller, 1995), for example by focusing on policies that will ensure that they are 'employers of choice' (Cappelli, 2000b). One of today's most important workforce challenges, therefore, is the retention of this group of talented, value creating employees (CLC, 1998a; Prewitt, 1999; Rankin, 2000; 
Deloitte \& Touche, 2001), so much so that it is being referred to as a 'war for talent' (Kaye \& Jordan-Evans, 2002: 32; Paton, 2002: 26).

In the effort to 'win' this war, organisations have shifted their attention to determining the variables that impact favourably on the retention of talent. However, research findings in this area remain mixed. Table 1 presents the results of previous research (Armstrong, 1996; Buckingham, 2000; Byham, Smith \& Paese, 1999; Cappelli, 2000a; CLC, 1998a, 1998b, 1999; Kaye \& Jordan-Evans, 2000).

\section{Table 1: Variables valued by talented employees}

\begin{tabular}{|c|c|}
\hline $\begin{array}{r}\text { Broad area } \\
\end{array}$ & Variables identified within area \\
\hline Compensation and benefits & $\begin{array}{l}\text { External equity } \\
\text { Internal equity } \\
\text { Variable pay (performance related) } \\
\text { Performance bonuses } \\
\text { Share options } \\
\text { Health benefits } \\
\text { Guaranteed base salary } \\
\text { Retirement benefits }\end{array}$ \\
\hline Organisational environment & $\begin{array}{l}\text { Open communication/transparency } \\
\text { Organisational change readiness } \\
\text { Competitive technology level } \\
\text { Organisational support \& commitment } \\
\text { Diversity } \\
\text { Formal information/knowledge sharing } \\
\text { Fairness } \\
\text { Networking opportunities } \\
\text { Job security } \\
\text { Senior team reputation } \\
\text { Company reputation } \\
\text { Organisational size and stability }\end{array}$ \\
\hline Work/development environment & $\begin{array}{l}\text { Empowerment and responsibility } \\
\text { Advancement opportunities } \\
\text { Personal 'buy-in' to business strategy } \\
\text { Mentoring programme } \\
\text { New opportunities/challenges } \\
\text { Performance evaluation \& feedback } \\
\text { Autonomy/independence } \\
\text { Recognition } \\
\text { Role clarity } \\
\text { Manager quality and integrity } \\
\text { Personal fit with company } \\
\text { Excellent co-worker quality } \\
\text { Internal mobility } \\
\text { Teamwork } \\
\text { 360-degree feedback } \\
\text { Challenging and meaningful work } \\
\text { Cutting-edge work } \\
\text { Development/learning opportunities } \\
\text { Pleasant daily work experiences } \\
\text { Productive \& friendly work relationships } \\
\text { Availability of teambuilding exercises } \\
\text { Status }\end{array}$ \\
\hline Work-life balance & $\begin{array}{l}\text { Business travel \& global exposure } \\
\text { Flexible working hours } \\
\text { Geographic location of work } \\
\text { Option to work from home } \\
\text { Extra vacation/longer annual leave } \\
\text { Childcare facilities }\end{array}$ \\
\hline
\end{tabular}


From the results shown in Table 1, it becomes apparent that previous research has found a mixture of intrinsic and extrinsic factors, with studies placing differential importance on these. For example, a recent Towers Perrin study (cited in HR Focus, 2003, 80(1):3) seems to emphasise extrinsic rewards, such as performance-based pay. Stewart (1997), too, focused retention suggestions on extrinsic factors, such as employee stock ownership, incentive pay and gainsharing bonuses. In contrast, Kaye \& Jordan-Evans (2002) reported that, notwithstanding the significance of extrinsic variables such as compensation in retaining talent, intrinsic factors such as meaningful and challenging work, good supervisors and development opportunities were considered higher in importance.

Organisations focusing on intrinsically important variables are considered to benefit by engendering an increased level of affective commitment amongst talent (DeConinck \& Bachmann, 1994; Meyer \& Allen, 1997; Michand, 2001). This is exhibited in behaviours and attitudes such as a strong belief in and acceptance of the values and goals of the organisation, a willingness to exert effort for the benefit of the organisation, and a desire to remain with the organisation (Tett \& Meyer, 1993). Given that Wyatt (2002, cited in HR Focus, 2003, 80(1):3) reported that organisations with high levels of employee commitment outperformed those with low levels of commitment by $200 \%$, focusing on intrinsic variables with an aim of increasing commitment amongst talent appears to make good business sense (Rankin, 2000).

As a result of the discrepancies in research findings, the current study was undertaken to determine the extent to which extrinsic and intrinsic variables were important to talented employees in a financial services organisation. As previous research was also undertaken mostly in the United States or the United Kingdom, this research also aimed to provide a South African viewpoint on the issue of talent retention.

\section{Method}

\section{Participants}

The population for this study consisted of a group of 115 employees at a financial services institution who form a recognised talent pool within the organisation. These employees, who, in accordance with the CLC's (2000) recommendations, are aware of their 'talent' status, were specifically identified by the organisation as high performers with potential senior managerial capacity, and have been through a leadership assessment process to determine their developmental needs in terms of future managerial competencies.

The final sample consisted of 64 employees from the talent pool. This represents a response rate of $55.7 \%$ of the population. The sample was skewed towards males, with only 13 female respondents included ( $20 \%$ of the sample). This proportion is, however, reflective of the gender distribution of the total population, where approximately $17 \%$ of the talent pool is female. Just over $90 \%$ of respondents fell between the ages of 30 and 49, with just over half the sample between the ages of 30 and 39. Exactly $50 \%$ of the sample had been with the organisation for over ten years, while $37.5 \%$ had tenure of less than four years. Most of the sample $(82.8 \%)$ worked in the organisation's Cape Town office.

\section{Measuring instruments and procedure}

This research was carried out in two phases. In the first, six in-depth semi-structured interviews were conducted with members of the talent pool with the purpose of gathering information regarding the variables considered important by the talent pool in a job or job offer. In particular, the interviews were concerned with uncovering any variables specific to the South African context that had not been mentioned in the retention literature but which could potentially have a significant effect on retention.

In the second phase of the research, the literature and interview information was used to compile a list of 49 workrelated variables that could potentially impact on talent retention. This list was distributed to all 115 members of the talent pool, with a request to rate these variables in terms of their level of importance on a four point Likert scale crucial ('this is a 'make or break' characteristic for me in a job'), fairly important ('this is a significant plus or minus factor, but not 'make or break'), neutral ('this would be nice to have, but it would not matter if it was not there'), and irrelevant ('this would not attract me to a company'). The variables were grouped into the four categories utilised by the CLC (1998a, 1998b, 1999) as shown in Table 1 above, although they were not specifically presented in the questionnaire in a format that depicted these categories. Participants were also asked to indicate, in rank order, which of the 49 variables they considered most important. The questionnaire also sought to establish participants' level of commitment to the organisation and their current job, through a direct question on this as well as asking participants to provide an indication of how long they anticipated voluntarily remaining with the organisation.

\section{Results}

Frequency counts were conducted on each variable listed in the questionnaire to determine the percentage of the sample rating each variable as crucial, fairly important, neutral or irrelevant. Table 2 summarises the results of these frequency counts.

Frequency counts were also conducted on the variables ranked by respondents as most important in a job to determine the five variables chosen most often by respondents. This revealed the top five variables to be 'Challenging and meaningful work', 'Advancement opportunities', 'Manager integrity and quality', 'Empowerment and responsibility', and 'New opportunities/challenges', all of which fall into the CLC's (1998a) Development/Work Environment category.

The interviews were instrumental in highlighting a variable not mentioned in previous research, but which is important to South African talent, namely that of employment equity and affirmative action. This variable is included in the 
results presented above. However, some respondents also used the questionnaire as an opportunity to raise issues that were not included in the questionnaire, and it is important to note these. The variables mentioned were the need for organisational provision of resources to help employees cope with stress, attention to the physical work environment (in terms of facilities, office space, storage space, and parking), and the negative effect on employees of corporate politics.

Participants' responses to the question concerning the selfperceived level of commitment to the organisation revealed that $71 \%$ felt a high level of commitment, $27 \%$ felt a medium level, and $2 \%$ had a low level of commitment. In terms of commitment to the current job, $89 \%$ reported being

Table 2: Absolute rating of importance of each variable highly committed, $9 \%$ reported a medium level, and $2 \%$ reported a low level of commitment. Interestingly, in answer to the question regarding how long participants anticipated remaining with the organisation, most respondents stated that they would stay with the organisation as long as they were challenged, enjoyed work and did not receive any better employment offers. Of the respondents who answered the question using a numerical indication of length of time (nineteen respondents), the following results were obtained: less than three years (four respondents), three to five years (four respondents), five to eight years (four respondents), eight to ten years (five respondents), and more than ten years (two respondents).

\begin{tabular}{|c|c|c|c|c|}
\hline Attribute & Crucial & $\begin{array}{c}\text { Fairly } \\
\text { important }\end{array}$ & Neutral & Irrele-vant \\
\hline \multicolumn{5}{|l|}{ Work/Development Environment } \\
\hline Empowerment \& responsibility & 73 & 25 & 2 & 0 \\
\hline Advancement opportunities & 69 & 31 & 0 & 0 \\
\hline Personal 'buy-in' to business strategy & 66 & 30 & 4 & 0 \\
\hline Mentoring programme & 30 & 42 & 25 & 3 \\
\hline New opportunities/challenges & 70 & 27 & 2 & 0 \\
\hline Performance evaluation \& feedback & 56 & 39 & 5 & 0 \\
\hline Autonomy/independence & 50 & 45 & 5 & 0 \\
\hline Recognition & 52 & 47 & 1 & 0 \\
\hline Role clarity & 42 & 44 & 14 & 0 \\
\hline Manager integrity \& quality & 78 & 22 & 0 & 0 \\
\hline Personal fit with company & 66 & 30 & 4 & 0 \\
\hline Excellent co-worker quality & 36 & 64 & 0 & 0 \\
\hline Internal mobility & 27 & 63 & 9 & 0 \\
\hline Teamwork & 34 & 56 & 8 & 2 \\
\hline 360-degree feedback & 28 & 45 & 27 & 0 \\
\hline Challenging \& meaningful work & 78 & 22 & 0 & 0 \\
\hline Cutting-edge work & 41 & 55 & 4 & 0 \\
\hline Development/learning opportunities & 69 & 30 & 1 & 0 \\
\hline Pleasant daily work experiences & 31 & 55 & 9 & 3 \\
\hline Productive \& friendly work relationships & 25 & 70 & 5 & 0 \\
\hline Availability of teambuilding exercises & 5 & 42 & 38 & 15 \\
\hline Status & 2 & 38 & 42 & 17 \\
\hline \multicolumn{5}{|l|}{ Compensation \& Benefits } \\
\hline External equity & 73 & 27 & 0 & 0 \\
\hline Internal equity & 66 & 28 & 6 & 0 \\
\hline Variable pay (performance related) & 49 & 44 & 6 & 2 \\
\hline Performance bonuses & 70 & 30 & 0 & 0 \\
\hline Share options & 66 & 31 & 3 & 0 \\
\hline Health benefits & 39 & 45 & 16 & 0 \\
\hline Guaranteed base salary & 39 & 45 & 16 & 0 \\
\hline Retirement benefits & 44 & 44 & 12 & 0 \\
\hline \multicolumn{5}{|l|}{ Organisational Environment } \\
\hline Open communication/transparency & 59 & 41 & 0 & 0 \\
\hline Organisational change readiness & 50 & 39 & 9 & 0 \\
\hline Competitive technology level & 45 & 44 & 11 & 0 \\
\hline Employment equity/affirmative action & 33 & 50 & 14 & 3 \\
\hline Organisational support \& commitment & 55 & 36 & 9 & 0 \\
\hline Diversity & 39 & 53 & 9 & 0 \\
\hline Formal information / knowledge sharing & 33 & 59 & 8 & 0 \\
\hline Fairness & 64 & 34 & 2 & 0 \\
\hline Networking opportunities & 29 & 50 & 22 & 0 \\
\hline Job security & 13 & 53 & 31 & 3 \\
\hline Senior team reputation & 50 & 48 & 2 & 0 \\
\hline Company reputation & 55 & 45 & 0 & 0 \\
\hline Organisational size \& stability & 13 & 67 & 16 & 4 \\
\hline \multicolumn{5}{|l|}{ Work-Life Balance } \\
\hline Business travel \& global exposure & 22 & 64 & 14 & 0 \\
\hline Flexible hours & 22 & 47 & 20 & 6 \\
\hline Geographic location of work & 27 & 44 & 23 & 6 \\
\hline Option to work from home & 3 & 41 & 50 & 5 \\
\hline Extra vacation/longer annual leave & 3 & 31 & 50 & 16 \\
\hline Childcare facilities & 2 & 11 & 36 & 51 \\
\hline
\end{tabular}




\section{Discussion and organisational recommendations}

From the results obtained for this study regarding commitment and anticipated residual tenure, it would seem that, despite high levels of current commitment to both the organisation and the job, the phenomenon of market-driven turnover is paramount amongst this group of talented employees (CLC, 1998a; Harvard Business Review, 2000). This can be seen from comments by the majority of the participants that they would base a decision to leave on the availability of better external employment offers, and the discrepancy between those members of the talent pool who put a figure to their anticipated continued employment, with nearly half of these participants anticipating remaining with the organisation for five years or less. This is roughly the average amount of time spent in an organisation by an employee who is committed to a more spiral or transitory career pattern (Muchinsky, Kriek \& Schreuder, 2002). These results seem to suggest that the talent pool in the organisation is experiencing continuance commitment rather than affective commitment. With continuance commitment, the employee bases his/her decision to remain with the organisation on perceptions of other available opportunities as well as the cost of leaving the organisation rather than on a more emotional attachment to the organisation as is found in affective commitment (Varner \& Fila, 2000). The fact that the variable of 'External equity' was rated as crucial or fairly important by the entire sample serves to emphasise that employees are conscious of what is occurring in the marketplace, and will respond according to perceived equity or inequity. External comparisons with compensation offered by other organisations can strongly impact on the effectiveness of compensation as a tool to retain employees (Armstrong, 1996; CLC, 1999; Rankin, 2000).

Although the highlighting of market-driven turnover and continuance commitment seems to suggest that this group of talented employees is largely concerned with extrinsic variables, the results obtained from participants' ratings indicate that a very significant proportion of the sample in this study rated almost all the variables in the questionnaire as either crucial or fairly important. It is therefore essential to take a more holistic view of the work environment and the employee-employer relationship. It appears that employees of this calibre place importance in a range of attributes, and where an organisation can provide most of these attributes adequately, these employees will be better retained. This finding is in accordance with those of nonSouth African studies, in which both intrinsic and extrinsic variables have been highlighted (Armstrong, 1996; Buckingham, 2000; Byham, Smith \& Paese, 1999; Capelli, 2000a; CLC, 1998a, 1998b, 1999; Kaye \& Jordan-Evans, 2000).

The only variables that did not have the same value attached were 'Availability of teambuilding exercises' and 'Status' from the category of Work/Development Environment (CLC, 1998a) and 'Option to work from home', 'Extra vacation/longer annual leave' and 'Childcare facilities' from the category of Work-Life Balance (CLC, 1998a). Interestingly, although teamwork was rated highly, respondents did not seem too concerned with teambuilding exercises. This result could be a reflection of the organisational context in which this research occurred, namely that teams already seem to be functioning well, and hence teambuilding is seen as unnecessary. With regard to the variable of 'Status', respondents in fact stated that the presence of status in the workplace and its use as a political tool was felt to have a negative impact on commitment and retention levels. The lack of interest in work-life issues could possibly be construed as a consequence of the skewed gender distribution in the sample. However, analysis of the women's results indicates that they did not place much importance on variables from this category, possibly because women at this level of employment tend to be economically empowered and can afford alternative means of childcare (Erasmus, 1997).

It is important to note, however, that employees' perceptions with respect to whether these variables are provided by the organisation is of utmost importance. Lack of communication of benefits available to employees could result in negative employee perceptions that do not match reality (Michand, 2001; HR Focus, 2003, 80(1):3). It may therefore be the case that, in some instances, it is communication to employees of the organisation's offerings that needs to be improved, and not necessarily the provision of specific attributes. These findings also support the idea of 'cafeteria-style' programmes, whereby employees can choose to include in their employment contract what is most important to them, thereby better meeting individual employee needs and enhancing the fit between the individual's and the organisation's requirements (Cappelli, 2000a; Mobley, 1982).

Although this research did highlight a concern with employment equity and affirmative action by members of the talent pool, with $83 \%$ of the sample rating it as crucial or fairly important, it did not emerge as one of the five most important variables. South African organisations should therefore take this variable into account, but immediate attention should perhaps be focused elsewhere.

Despite the findings discussed above whereby both intrinsic and extrinsic variables were rated as crucial or fairly important, participants' rankings of five variables considered highest in importance is quite telling. The five most important variables that emerged in this regard for immediate organisational focus are those of 'Challenging and meaningful work', 'Advancement opportunities', 'High manager integrity and quality', 'Empowerment and responsibility', and 'New opportunities/challenges'. It is worth noting that all these variables are intrinsic in nature and that they all fall into the category of Work/Development Environment (CLC, 1998a, 1998b, 1999). This focus on intrinsic variables indicates that the continued provision by the organisation of these variables is also considered important in decisions to leave. While the organisation may not be able to completely control the employees' decisions to leave by means of manipulating these variables, it seems as if focusing on these may still have a considerable influence. These variables have been found to impact positively on an employee's level of affective commitment, which has been postulated to increase retention, particularly amongst high performing employees (DeConinck \& 
Bachmann, 1994; Meyer \& Allen, 1997). These results also support an organisational focus on satisfaction: Meyer and Allen (1997) have stated that personal fulfilment is the main process whereby affective commitment develops; thus, if the organisation conveys a supportive and just environment where individual contribution is valued, work experiences will be especially fulfilling.

The fact that intrinsic variables proved most important for this sample highlights Rankin's (2000) recommendation that retention strategies treat employees as if they were clients. This, according to Rankin (2000), will increase the success of such strategies as they convey the organisation's interest in the well-being and development of their members, which can be accomplished through recognising and rewarding personal goals, nurturing employees' strengths and providing them with appropriate opportunities and the discretion to solve problems and meet challenges.

It is suggested that future research aim to build on the results of this exploratory study in order to develop a comprehensive model of talent retention. In particular, the relationship between intrinsic and extrinsic variables needs to be clarified. The current research has clearly demonstrated that both are important. However, the current research also seems to suggest that employees value intrinsic attributes and demonstrate affective commitment only as long as they perceive that they are in a position of external equity. As soon as this situation changes, though, it appears as if they are likely to leave the organisation to pursue better offers until a sense of equity is regained. This tentative suggestion needs to be explicitly tested with other samples. It is also recommended that future research in this area include an already developed and accepted scale that measures the facets of commitment in order to build up a comprehensive theoretical model of talent retention that includes this construct.

In addition, while the results discussed above indicate support for the results of similar research undertaken outside of South Africa, a mention must be made of the fact that the current research was undertaken in one industry in South Africa, namely that of financial services. The fact that the company concerned operates in a global market, with branches overseas, may have assisted in obtaining a sample that is similar in many respects to their overseas counterparts. It is therefore recommended that future South African researchers in this area undertake to extend this work to other industries in order to build up a research base that reflects the local context in addition to global commonalities.

\section{Conclusion}

This research has provided some evidence that South African talent may largely value the same variables that have been identified as important in previous research conducted outside of the South African context. The most significant variable added to the list compiled from literature is that of a concern with employment equity and affirmative action. With regard to the relative importance of intrinsic and extrinsic variables, however, no definite conclusions can be drawn from these results. Although this research has shown that intrinsic variables remain high in importance, this does not in any way imply, however, that the extrinsic variables are not at all influential in decisions to leave. In fact, these were shown to be highly valued, and the results indicate that market opportunities are also a significant factor in such decisions, regardless of current levels of affective commitment. Results in fact seemed to suggest that continuance rather than affective commitment was influential in decisions to remain with the organisation. Organisations therefore certainly face an enormous challenge in retaining their talented core employees as this retention relies heavily on both external equity and the provision of a positive work environment.

\section{References}

Arkin, A. 2001. 'Double jeopardy', People Management, 7(4): $26-31$.

Armstrong, M. 1996. Employee reward. London: Institute of Personnel Development.

Buckingham, G. 2000. 'Same indifference', People Management, 6(4): 44 - 46.

Byham, W. C., Smith, A. \& Paese, M. 1999. Growing your own: Building future leadership talent (Whitepaper). [Online] URL: http://ddiworld.com

Cappelli, P. 2000a. 'A market-driven approach to retaining talent', Harvard Business Review, 78(1): 103 - 112.

Cappelli, P. 2000b. 'Managing without commitment', Organizational Dynamics, 28(4): 11 - 14.

Harvard Business Review, 2000. 'Commitment without loyalty'. [On-line] URL: http://www.search.epnet.com

Corporate Leadership Council. 1998a. Employee retention: New tools for managing workforce stability and engagement. Washington: CLC. Workforce Commitment Series, 2.

Corporate Leadership Council. 1998b. Workforce turnover and firm performance: The new business case for employee retention. Washington: CLC. Workforce Commitment Series, 1.

Corporate Leadership Council. 1999. The compelling offer: A quantitative analysis of the career preferences and decisions of high value employees. Washington: CLC. Workforce Commitment Series, 3.

Corporate Leadership Council. 2000. Challenges in managing high-potential employees: Results of the Council's membership survey. Washington: CLC. Managing high potential employees series, 1.

DeConinck, J. B. \& Bachmann, D. P. 1994. 'Organisational commitment and turnover intentions of marketing managers', Journal of Applied Business Research, 10(3): 87 $-96$. 
Erasmus, B. 1997. 'Women power: Aspects of work life', Agenda, 35: 35 - 43 .

Feller, R. W. 1995. 'Action planning for personal competitiveness in the 'broken workplace", Journal of Employment Counseling. [On-line] URL: http://www.epnet.com/ehost/login/html

Flood, P. 2002. 'Make sure you can navigate the gap between a job and a career', Sunday Times Business Times, June 9:2.

Kaye, B. \& Jordan-Evans, S. 2000. 'Retention: Tag, you're it!' Training and Development, 54(4): 29 - 34.

Kaye, B. \& Jordan-Evans, S. 2002. 'Retention in tough times', Training and Development, 56(1): 32 - 37.

Kerka, S. 1995. 'Adult career counselling in a new age', Eric Digest No. 167. [On-line] URL: http://ericacve.org/docs/adult.htm

March, J. G. \& Simon, H. A. 1958. Organisations. New York: Wiley.

Meyer, J. P. \& Allen, N. J. 1997. Commitment in the workplace: Theory, research and application. London: Sage Publications.

Michand, L. 2001. 'Turning the tables on employee turnover', RSI: Roofing, Siding, Insulation, 78(1): 15 - 16.

Mobley, W. H. 1982. Employee turnover: Causes, consequences and control. Reading, Massachusetts: Addison-Wesley Publishing Company.

Muchinsky, P., Kriek, H.J. \& Schreuder, A. 2002. Personnel psychology. Cape Town: Oxford University Press.

Paton, N. 2002. 'Talent magnet', Personnel Today, December 11: 26-27.

Prewitt, E. 1999. 'How to keep your company's star employees', Harvard Management Update, 4(5): 4 - 5.

Quinn, J. B., Anderson, P. \& Finkelstein, S. 1996. 'Managing professional intellect: Making the most of the best', Harvard Business Review, March-April: $71-80$.

Rankin, M. J. 2000. 'Winning the war for talent: How to become an employer of choice', Trusts and Estates, 139(4): $54-57$.

Deloitte \& Touche. Human Capital Corporation. 2001. Retaining talent: The leader's role.

HR Focus, 80(1), 2003: 3-5. Rewards: The not-so-secret ingredient for managing talent'.

Schreuder, A. \& Theron, A. 2001. Careers: An organisational perspective. Cape Town: Juta.
Stewart, T. A. 1997. 'Brain power', Fortune, March 17: 67 -68 .

Sveiby, K. E. 1997. The new organizational wealth: Managing and measuring knowledge-based systems. San Francisco: Berret-Koehler Publishers.

Tett, R. P. \& Meyer, J. P. 1993. 'Job satisfaction, organisational commitment, turnover intention, and turnover: Path analyses based on meta-analytic findings', Personnel Psychology, 46(2): 259 - 292.

Varner, J. \& Fila, J. 2000. Will they stay? Understanding organisational commitment. [On-line] URL: http://www.wlu.ca/ wwwsbe/sbe2000/html/Will\%20They\% 20Stay 20 article.doc 
